\title{
ARTIGOS
}

\section{ABSENCE OF CLINICAL ABNORMALITIES SUGGESTING RENAL INVOLVEMENT DURING THE LONG-TERM COURSE OF VISCERAL LEISHMANIASIS}

\author{
Reinaldo Martinelli, Rosemarie Lorenço e Heonir Rocha
}

\begin{abstract}
Abnormalities of renal function have been demonstrated in patients with visceral leishmaniasis; although there was a trend toward normalization following antiparasitic therapy, some abnormalities persisted. With the purpose of studying the longterm clinical course of renal involvement in visceral leishmaniasis, 32 patients with a diagnosis of this parasitic disease were evaluated in the endemic area and at least 6 months after the clinical cure of the disease and compared with a control group of 28 individuals. No patient had a history or clinical findings suggestive of renal disease and all were normotensive. Laboratory evaluation was normal in all except 3 patients with abnormal urinalysis. Mild proteinuria and microscopic hematuria were seen in a single urinalysis in one patient (although three other urinalysis were normal), and leucocyturia in two female patients. It was concluded that the renal involvement in visceral leishmaniasis is mild and transient, with normal renal function observed on long-term follow-up after cure of the parasitic infection.
\end{abstract}

Key words: Visceral leishmaniasis. Nephropathy. Reversibility. Clinical Course. Parasitic disease.

Renal involvement has been well documented in patients with visceral leishmaniasis 278925 . Although most of the reports have been concerned with the pathological changes 27825 , in a prospective clinical study 9 it was demonstrated that some impairment of renal function was present in $60 \%$ of hospitalized patients. This consisted of abnormalities of urinalysis $(51 \%)$, increased urinary protein excretion $(57 \%)$, creatinine clearance below $80 \mathrm{ml} / \mathrm{min}(37 \%)$ and abnormal acid load test $(66 \%)$. After therapy of the parasitic disease, although there was a trend toward normalization of the renal function, about $25 \%$ of the patients continued to have abnormalities in urinalysis, $24 \mathrm{hr}$ urinary protein excretion and/or creatinine clearance. Questions about reversibility of such abnormalities and the role of the parasitic disease as a cause of progressive renal disease are still unanswered. The purpose of the present study was to determine the long-

Department of Medicine, Federal University of Bahia, Salvador - Bahia - Brazil.

This work was supported by grants n. 40.3684/82 (Conselho Nacional de Desenvolvimento Científico e Tecnológico) and AI-16282 of National Institute of Health.

Endereço para correspondência: Dr. Reinaldo Martinelli, M. D. - Hospital Prof. Edgard Santos, Laboratório 1117 Nefrologia - Rua João das Botas, s/n - Canela - 40000 Salvador - Bahia - Brasil.

Recebido para publicação em 26/6/1986. term clinical course of clinical signs of renal involvement in visceral leishmaniasis.

\section{MATERIAL AND METHODS}

A total of 32 patients of both sexes with a proven diagnosis of visceral leishmaniasis in the past. Were studied all the patients had the diagnosis documented by the demonstration of leishmania on bone-marrow smear and were treated with intravenous $\mathrm{N}$-methylglucamine. Cure was defined as disappearance of parasites from the bone-marrow and subsidence of clinical signs of the disease. The patients were reevaluated in the endemic area at least 6 months following the cure of the parasitic disease. Besides history and physical examination, urinalysis and serum determination of BUN and creatinine were also performed. As a control group, 28 subjects with the same age range and living in the same endemic area, with no previous or present documentation of leishmanial infection were similarly evaluated.

\section{RESULTS}

Among the patients with past diagnosis of visceral leishmaniasis there were 15 male and 17 female, with a mean age of 9.7 years, ranging from 1 to 19 years (Table 1). Twenty four were younger than 12 years of age. Two patients were re-evaluated between 6 and 12 months after initial diagnosis, 7 between 13 and 21 months, 6 between 25 and 36 months, 17 
Martinelli R, Lorenço R, Rocha H. Absence of clinical abnormalities suggesting renal involvement during the long-term course of visceral leishmaniasis. Revista da Sociedade Brasileira de Medicina Tropical 19: 209-212, Out-Dez, 1986.

Table 1 - Renal involvement in visceral leishmaniasis: demographic data

\begin{tabular}{lcc}
\hline & $\begin{array}{c}\text { Visceral } \\
\text { leishmaniasis }\end{array}$ & Control \\
Sex & 15 & 15 \\
Male & 17 & 13 \\
Female & 32 & 28 \\
Total n. of cases & & \\
\hdashline Age Year & $9.7 \pm 44$ & $9.8 \pm 4.9$ \\
Mean & $(1$ to 19$)$ & $(2$ to 19$)$ \\
(Range) & & \\
\hline Reevaluation Months & 2 & \\
$6-12$ & 7 & \\
$13-24$ & 6 & \\
$25-36$ & 5 & \\
$37-48$ & 1 & \\
$49-60$ & 11 & \\
$>60$ &
\end{tabular}

between 36 and 60 months and 11 patients were reevaluated more than 60 months after the therapy. The control group was composed of 15 males and 13 females with a mean age of 9.8 years, ranging from 2 to 19 years; 16 were younger than 12 years old.

No history or clinical findings suggestive of renal disease could be detected in either group studied. The mean blood pressure was $102 / 60 \mathrm{mmHg}$ for the patients with history of visceral leishmaniasis and $100 / 600 \mathrm{mmHg}$ in the control group (Table 2). In one

Table 2 - Renal involvement in visceral leishmaniasis: clinical evaluation

\begin{tabular}{lcc}
\hline & $\begin{array}{c}\text { Visceral } \\
\text { leishmaniasis } \\
102 / 60\end{array}$ & $\begin{array}{c}\text { Control } \\
\text { Blood pressure, mmHg } \\
\text { (mean) }\end{array}$ \\
\hdashline $\begin{array}{l}\text { Urinalysis } \\
\quad \text { Proteinuria/hematuria }\end{array}$ & 1 & 0 \\
$\quad$ Leucocyturia & 2 & 1 \\
\hline $\begin{array}{l}\text { Mean serum creatinine, } \\
\text { mg/dl. }\end{array}$ & $0.93 \pm 0.2$ & $0.97 \pm 0.3$ \\
$\begin{array}{l}\text { Mean blood urea nitrogen, } 11.0 \pm 3.4 \\
\text { mg/dl. }\end{array}$ & $10.2 \pm 2.7$ \\
\hline
\end{tabular}

patient, seen 3 years after the initial diagnosis of the parasitic disease, mild proteinuria and microscopic hematuria were initially detected, although 3 other urinalysis, done at different intervals, were normal.
Leucocyturia (more than 5 leucocytes per high power field) were documented in 2 patients (females) and in one of the control group (male). The levels of BUN and serum creatinine were normal in all patients but one in the control group, who had a slight elevation of serum creatinine $(1.5 \mathrm{mg} / \mathrm{dl})$. The mean serum creatinine was $0.93 \mathrm{mg} / \mathrm{dl}$ and BUN $11.0 \pm 3.4 \mathrm{mg} / \mathrm{dl}$ for the group of patients with past diagnosis of visceral leishmaniasis and $0.97 \mathrm{mg} / \mathrm{dl}$ and $10.2 \pm 2.7 \mathrm{mg} / \mathrm{dl}$, respectively, for the control group.

\section{DISCUSSION}

Renal involvement has been demonstrated in association with some parasitic infections 31721 . Even though parasite antigen has been demonstrated in the kidney in only a few of such cases ${ }^{13} 19$, there is enough clinical and experimental data to support this association $6{ }^{14}$. In visceral leishmaniasis, although $L$. donovani related antigenic material has not been demonstrated in the glomeruli of the patients, the high prevalence of renal abnormalities among infected patients and the findings of interstitial nephritis and mild forms of glomerulonephritis, as well as, glomerular deposition of immunoglobulins and complement in these patients, strongly supports an immunological basis for the renal involvement 278925 .

In a previous report Dutra et $\mathrm{al}^{9}$ demonstrated improvement of renal function in some patients after treatment of the parasitic diseases, however, a significant number had persistent renal dysfunction. It should be stressed that this evaluation was done soon after therapy, when several serologic and immunologic abnormalities were still present. In the present study, done in an endemic small village (where more sensitive techniques could not be used), renal dysfunction, as evaluated by clinical and laboratory parameters, could not be demonstrated in any of the patients more than 6 months after the diagnosis and cure of visceral leishmaniasis.

In two patients with past diagnosis of leishmaniasis, and in one of the control group, more than 5 leucocytes per high power field were documented. In the absence of clinical symptoms, bacteriuria and positive urine culture, the diagnosis of urinary tract infection can not be entertained. Another female patient had proteinuria and microscopic hematuria in one urinalysis, even though three other urinalysis, and the levels of serum creatinine and BUN were persistently normal. In view of the abnormal urinalysis, renal disease can not be ruled out in this patient since transient, slight abnormalities in the urinalysis may indicate early stages of some nephropathy. Also, renal disease can not be excluded in a child, in the control group, with slight elevation of serum creatinine, despite a normal urinalysis. 
Martinelli R, Lorenço R, Rocha H. Absence of clinical abnormalities suggesting renal involvement during the long-term course of visceral leishmaniasis. Revista da Sociedade Brasileira de Medicina Tropical 19: 209-212, Out-Dez, 1986.

The borderline evidence of renal disease in just one of 32 patients after diagnosis of visceral leishmaniasis, and a similar finding in one patient of the control group, argues against a primary role of the leishmaniasis in the pathogenesis of chronic renal disease. The reversibility of the disease after cure of the visceral leishmaniasis, as also reported in abstract form in one case ${ }^{5}$, was not surprising. The incidence of renal disease in a leishmaniasis endemic area does not seem to be higher than in other areas. Second, disappearance of the renal disease associated with cure of an infectious process has been demonstrated in other conditions such as bacterial endocarditis ${ }^{24}$, poststreptococcal and post-staphylococcal infections 101623 , typhoid fever ${ }^{24}$, chronic septicemic salmonellosis ${ }^{11}$, syphilis 121520 and infectious mononucleosis ${ }^{18}$. Since the pathogenesis of the glomerular disease in such instance is thought to be immunologically mediated, it is conceivable that cure of the infection leads, consequently, to the disappearance of the antigenic source. In the absence of a persistent antigenic source, hypertension, vascular or extensive glomerular lesions ${ }^{14}$ reversibility of the renal involvement in leishmaniasis should, in fact, be expected.

\section{RESUMO}

Anormalidades das funções renais têm sido demonstradas em pacientes portadores de leishmaniose visceral; embora haja tendência à normalização logo após o tratamento antiparasitário, algumas dessas anormalidades persistem. Com o propósito de estudar o curso clínico a longo prazo do envolvimento renal na leishmaniose visceral, 32 pacientes foram estudados na área endêmica, pelo menos 6 meses após a cura clínica da doença, e comparado a um grupo-controle de 28 individuos. Em nenhum paciente se documentou história ou dados clínicos sugestivos de doença renal. A avaliação laboratorial foi normal em todos os pacientes, exceto $3 \mathrm{com}$ sumários de urina anormais em um, proteinúria leve e hematúria microscópica num único sumário de urina (três outros foram normais) e leucocitúria em dois outros pacientes. Concluiu-se que na leishmaniose visceral o envolvimento renal é discreto e transitório, havendo desaparecimento das alteraçōes sugestivas de disfunção após a cura da doença parasitária.

Palavras chaves: Leishmaniose visceral. Nefropatia. Reversibilidade. Curso Clínico.

\section{REFERENCES}

1. Adler SG, Kopple JD. Factors influencing the progression of renal insufficiency. Seminars of Nephrology 3: 335343,1983
2. Andrade ZA, Iabuki K. A nefropatia do calazar. Revista do Instituto de Medicina Tropical de São Paulo 14: 31 54, 1972.

3. Andrade ZA, Rocha H. Schistosomal glomerulopathy. Kidney International 16: 23-29, 1979.

4. Baldwin DS. Chronic glomerulonephritis: non-immunologic mechanisms of progression of glomerular damage. Kidney International 21: 109-120, 1982.

5. Ben Maiz H, Ben Mousse F, Kheder MA, Ayed KL, Ben Ayed H. Glomerular involvement in a human kala-azar: a clinical and histological study of one case. In: Abstract IX $^{\text {th }}$ International Congress of Nephrology, Los Angeles. p. 107A, 1984.

6. Carvalho EM, Andrews BS, Martinelli R, Dutra M, Rocha H. Circulating immune complexes and theumatoid factor in visceral leishmaniasis and schistosomiasis. The American Journal of Tropical Medicine and Hygiene 32: 61-68, 1983.

7. De Brito T, Hoshino-Shimizu S, Amato Neto V, Duarte IS, Penna DO. Glomerular involvement in human kalaazar: a light immunofluorescent and electron microscopic study based on kidney biopsies. The American Journal of Tropical Medicine and Hygiene 24: 9-18, 1975.

8. Duarte MIS, Silva MRR, Goto H, Nicodemo EL, Amato Neto V. Interstitial nephritis in human kala-azar. The Transactions of the Royal Society of Tropical Medicine and Hygiene 77: 531-537, 1983.

9. Dutra M, Martinelli R, Carvalho EM, Rodrigues LE, Brito $E$, Rocha $H$. Renal involvement in visceral leishmaniasis. American Journal of Kidney Disease 6: 22-27, 1985

10. Garcia R, Rubio L, Rodriguez-Iturbe B. Long-term prognosis of epidemic post-streptococcal glomerulonephritis in Maracaibo: Follow-up studies 11-12 years after the acute episode. Clinical Nephrology 15:291-298, 1981.

11. Higoshi GI, Farid Z, Bassily S, Miron WF. Nephrotic syndrome in schistosomiasis mansoni complicated by chronic salmonellosis. The American Journal of Tropical Medicine and Hygiene 24: 713-714, 1975.

12. Hillier MD, Webster ADB, Eisinger AJMF. Nephrotic syndrome: a complication of secondary syphilis. British Medical Journal 4: 404, 1971

13. Hoshino-Shimizu S, Brito T, Kanamura HY, Couto AL, Silva AD, Campos AR, Penna DO, Silva LC. Human schistosomiasis: schistosoma antigen detection in renal glomeruli. The Transactions of the Royal Society of Tropical Medicine and Hygiene 70: 492-496, 1977.

14. Kager PA Hock CE, Hannema AJ, Reis PH, von dem Borne $A E G R$. High $C_{1 q}$ levels, low $C / C_{1 q}$ ratio and high levels of circulating immune complexes in kala-azar. Clinical Immunology and Immunopathology 23: 86-93, 1982.

15. Kaplan BS, Wigleswirth FW, Marks MI. The glomerulopathy of congenital syphilis - an immune complex deposit disease. Journal of Pediatrics 81: 1159 , 1972.

16. Kim Y, Michael AF. Chronic bacteriuria and nephritis Annual Review of Medicine 29: 319-325, 1978. 
Martinelli R, Lorenço R, Rocha $\mathbf{H}$. A bsence of clinical abnormalities suggesting renal involvement during the long-term course of visceral leishmaniasis. Revista da Sociedade Brasileira de Medicina Tropical 19: 209-212, Out-Dez, 1986.

17. Klei TR, Crowell WR, Thompson PE. Ultrastructural glomerular changes associated with filariasis. The American Journal of Tropical Medicine and Hygiene 23: $608-618,1974$.

18. Lee $\mathrm{S}$, Kjllstrand CM. Renal disease in infectious mononucleosis. Clinical Nephrology 9: 236-240, 1978.

19. Lopes JD, Moreira AAB, Campos R, Kanamura HY, Hoshino-Shimizu S, Gayotto LCC, Silva LC. Circulating antigens, antibodies and glomerular immune complexes in mice with unisexual $S$. mansoni infection. Revista do Instituto de Medicina Tropical de São Paulo 23: 155$160,1981$.

20. Losito A, Buccorelli E, Nasi-Bernadetti F, Lato M. Membranous glomerulonephritis in congenital syphilis. Clinical Nephrology 12: 32-37, 1979.

21. Nagle RB, Ward PA, Lindsly HB. Experimental infection with African trypanosomes. VI. Glomerulonephritis involving the alternate pathway of complement activation. The American Journal of Tropical Medicine and Hygiene 23: 15-26, 1974.

22. Neugarten J, Gallo GR, Baldwin DS. Glomerulonephritis in bacterial endocarditis. American Journal of Kidney Disease 3: 371-379, 1984.

23. Potter EV, Lipschultz SA, Abidh S, Ponn-king T, Earle DP. Twelve to seventeen year follow-up of patients with poststreptococcal glomerulonephritis. New England Journal of Medicine 307: 725-729, 1982.

24. Sitprija V, Pipatanagul V, Boonpucknaving V, Boonpucknavig S. Glomerulitis in typhoid fever. Annals of Internal Medicine 81: 210-213, 1974.

25. Weisinger JR, Pinto A, Velazquez GA, Bronstein I, Dessim JJ, Duque JF, Montenegro J, Tapams F, Rousse AR. Clinical and histological kidney involvement in human kala-azar. The American Journal of Tropical Medicine and Hygiene 27: 357-359, 1978. 